九州大学学術情報リポジトリ

Kyushu University Institutional Repository

\title{
Reaction of Tobacco and Rice Leaf Tissue Infiltrated with Burkholderia glumae or B. gladioli
}

Furuya, Naruto

Laboratory of Plant Pathology, Faculty of Agriculture, Kyushu University

I iyama, Kazuhiro

Laboratory of Plant Pathology, Faculty of Agriculture, Kyushu University

Ueda, Yasuko

Laboratory of Plant Pathology, Faculty of Agriculture, Kyushu University

Matsuyama, Nobuaki

Laboratory of Plant Pathology, Faculty of Agriculture, Kyushu University

https://doi.org/10.5109/24190

出版情報 : 九州大学大学院農学研究院紀要. 42 (1/2)，pp.43-51，1997-12. Kyushu University バージョン：

権利関係 : 


\title{
Reaction of Tobacco and Rice Leaf Tissue Infiltrated with Burkholderia glumae or B. gladioli
}

\author{
Naruto Furuya, Kazuhiro Iiyama, Yasuko Ueda* \\ and Nobuaki Matsuyama \\ Laboratory of Plant Pathology, Faculty of Agriculture, \\ Kyushu University, Fukuoka 812-81, Japan \\ (Received July 25, 1997 and Accepted August 25, 1997)
}

\begin{abstract}
Reaction of tobacco and rice leaf tissue infiltrated with either strains of Burkholderia glumae or B. gladioli was investigated. Visual alteration areas of tobacco leaf at sites infiltrated with high concentration (more than $10^{7}$ cells $/ \mathrm{ml}$ ) of the bacteria were categorized into two types, one causing necrosis with hypersensitive-like reaction (HLR) within $24 \mathrm{hr}$ of infiltration, and the other developing only yellowish discoloration. Living bacterial cells and the toxoflavin were effective for necrosis induction, whereas heat-killed cells, bacterial lipopolysaccharide (LPS) and extracellular polysaccharide (EPS) were ineffective. In the case of B. glumae, necrosis occurred with toxoflavin producing strains. No necrotic lesions developed with toxoflavin non-producing strains. All strains of $B$. gladioli induced necrosis with water soaking lesions in tobacco leaf. Infiltration of toxoflavin producing strains of $B$. glumae and B. gladioli to rice leaf caused necrosis or a chlorotic spot on the leaf. A toxoflavin (lose of more than $100 \mu \mathrm{g} / \mathrm{ml}$ induced necrosis, suggesting close relationship between virulence to rice and necrosis inductivity to an uncongenial plant such as tobacco. Thus, the principle which induces HLR can be regarded as an essential attribute for pathogenicity. In contrast to the reaction of rice leaf toward toxoflavin, necrosis in tobacco leaf could not simply be a reaction to toxoflavin but rather to additional unknown factors.
\end{abstract}

\section{INTRODUCTION}

The hypersensitive reaction (HR) of tissues infected with fungi and viruses occurs widely in plants. The ability of bacteria to elicit HR was discovered by Klement and coworkers in 1963. Since this first report on the pseudomonads-tobacco combination, HR has been confirmed for various host- or uncongenial plant-bacteria combinations. To date, however, there are no reports on HR for Burkholderia glumae (or B. gladioli) and rice varieties or uncongenial tobacco cultivars. In the present study, the reaction of tobacco and rice plants to strains of $B$. glumae and B. gladioli, recognized as closely related bacteria, were investigated by the leaf infiltration technique to characterize pathological properties of these bacterial strains.

\section{MATERIALS AND METHODS}

\section{Bacterial strains}

Eighteen strains of B. glumae and twelve strains of B. gladioli were used (Table 1). Each strain was grown on potato semi-synthetic agar (PSA) medium containing $5 \mathrm{~g}$

\footnotetext{
* Present address: City of Shimonoseki, Urban Development Dept., Park Division, Yamaguchi 750, Japan.
} 
Table 1. Strain of B. glumae and B. gladioli used in this experiment.

\begin{tabular}{|c|c|c|c|c|c|}
\hline Strain & Origin & Source & Strain & Origin & Source \\
\hline B. glumae & & & B. gladioli pv. gladioli & & \\
\hline Ku8104 & Rice grain & $\mathrm{KU}$ & MAFF301064 & Freesia & MAFF \\
\hline Ku8105 & " & " & MAFF301580 & Dendrobium & $"$ \\
\hline Ku8112 & $"$ & $"$ & MAFF302515 & Tulip & $"$ \\
\hline Ku8113 & " & " & MAFF 302537 & Onion & " \\
\hline Ku8114 & $"$ & " & MAFF302544 & Rice & " \\
\hline 8012 & " & KNAES & NIAS1064 & Freesia & NLAS \\
\hline 8015 & " & " & NIAS1065 & " & " \\
\hline 8020 & $"$ & $"$ & E-14 & Rice & KU \\
\hline N7401 & Rice seedling & NIAS & ATCC10248 & Gladiolus & ATCC \\
\hline N7501 & $"$ & $"$ & & & \\
\hline N7504 & $"$ & " & & & \\
\hline N7505 & $"$ & " & B. gladioli pv. unidentified & & \\
\hline 2 & Rice grain & KNAES & MAFF302409 & Adzuki bean & MAFF \\
\hline III & " & " & MAFF302418 & Green gram & $"$ \\
\hline AZ8224 & $"$ & Dr. Azegami & MAFF302424 & Cymbidium & " \\
\hline AZ84448 & " & " & & & \\
\hline 805 & unknown & NIAS & & & \\
\hline MAFF301169? & Rice & MAFF & & & \\
\hline
\end{tabular}

a) Abbreviations for culture collections: KU, Kyushu University; KNAES, Kyushu National Agricultural Experiment Station; NIAS, National Institute of Agricultural Sciences; MAFF, Ministry of Agriculture, Forestry and Fisheries; ATCC, American Type Culture Collection.

peptone, 15 g sucrose, $2 \mathrm{~g} \mathrm{Na}_{2} \mathrm{HPO}_{4} \cdot 12 \mathrm{H}_{2} \mathrm{O}, 0.5 \mathrm{~g} \mathrm{Ca}\left(\mathrm{NO}_{3}\right)_{2} \cdot 4 \mathrm{H}_{2} \mathrm{O}, 15 \mathrm{~g}$ agar in $1,000 \mathrm{ml}$ of potato $(300 \mathrm{~g})$ decoction, $\mathrm{pH} 7.0$, at $30^{\circ} \mathrm{C}$ for $48 \mathrm{hr}$.

\section{Test plants}

Tobacco plants (Nicotiana tabacum L. cvs. Bright Yellow, White Burley, Xanthi, Xanthi-nc and Judy's Pride) were grown at around $25^{\circ} \mathrm{C}$ under greenhouse conditions. At the 8th to 9th leaf stages, the fully expanded third and fourth leaves were served for the infiltration assay. Rice plants (Oryza sativa cvs. Chugoku No. 45, Asominori, Aichiasahi, Koshihikari, Nipponbare, Kinmaze, Norin No. 29, Kuju and Rantai Emas, O. nivara, O. barthii, $O$. eichingeri, $O$. glaberrima and $O$. punctata) were grown under normal greenhouse conditions and fully expanded leaves were used for the infiltration assay.

\section{Preparation of inoculum and infiltration into the leaf tissue}

Bacterial cells of each strain grown on PSA were suspended in sterilized distilled water so as to be $10^{9} \mathrm{cfu} / \mathrm{ml}$ approximately. The leaf was pin-pricked at a site to be infiltrated. Subsequently, bacterial suspension was infiltrated with a hypodermic syringe into the intercellular spaces through the wound. Five leaves, at least, were infiltrated with each strain. In addition living whole bacterial cells, killed cells, extracellular polysaccharide (EPS), lipopolysaccharide (LPS) and toxoflavin from B. glumae and B. 
gladioli were also infiltrated. To prepare killed bacterial cells, heat-treatment, chloroform treatment and UV irradiation were carried out. To kill the bacterial cells by heating, $20 \mathrm{ml}$ of each bacterial suspeusion of B. glumae or B. gladioli (conc. ca. $10^{9}$ $\mathrm{cfu} / \mathrm{ml}$ ) was autoclaved at $121^{\circ} \mathrm{C}$ for $20 \mathrm{~min}$. Chloroform treatment was conducted as follows: $30 \mathrm{ml}$ of bacterial suspension in a $500-\mathrm{ml}$ beaker was incubated in a 2,000-ml beaker moistened with $100 \mathrm{ml}$ of chloroform, and wrapped with aluminum foil. The suspension was exposed to chloroform vapor under gentle shaking for $4 \mathrm{hr}$. Five ml of the suspension was placed in a Petri-dish ( $9 \mathrm{~cm}$ in diameter) and irradiated under UV light (TOSHIBA GL 15W) at a distance of $30 \mathrm{~cm}$ for $4 \mathrm{hr}$. EPS and LPS extraction was performed as previously described by Evans, L. R. and Linker, A. (1973) and Lucas, L. T. and Grogan, R. G. (1969a and 1969b), respectively. Toxoflavin produced by B. glumae or $B$. gladioli was extracted according to the method as described previously (liyama $e t$ al., 1994). The reaction of the infiltrated leaves was observed periodically up to $96 \mathrm{hr}$ after infiltration under the greenhouse conditions.

\section{RESULTS}

\section{Reaction of tobacco leaf tissue to bacterial infiltration}

Tobacco leaves infiltrated with ca. $10^{9} \mathrm{cfu} / \mathrm{ml}$ suspensions of toxoflavin producing strains induced necrosis resembling HR within $24 \mathrm{hr}$ (Fig. 1 and Table 2). In the case of
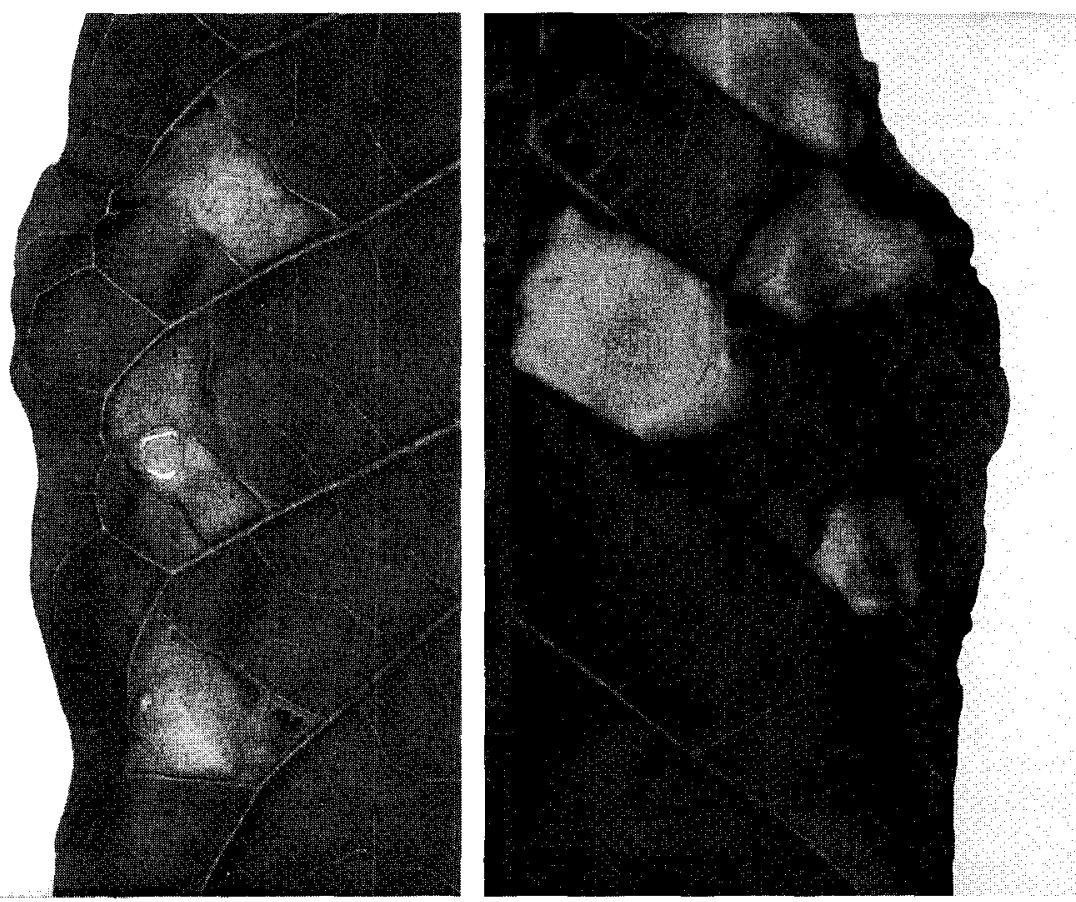

Fig. 1. Symptoms produced in tobacco leaves by Burkholderia glumae (left) and B. gladioli (right) at 24th hr after infiltration. Cell suspensions containing about $10^{4} \mathrm{cfu} / \mathrm{ml}$ were infiltrated into each leaf segment. 
B. gladioli, two toxoffavin non-producing strains (NIAS1065 and E-14) also induced necrosis in tobacco leaf tissue. On the other hand, yellowish discoloration appeared at areas infiltrated with toxoflavin non-producing strains of B. glumae up to 48th hr, but the same symptoms were not produced by toxoflavin producing strains. Infiltration of pure water did not cause the symptoms in any leaves.

Table 2. Relationship between toxoflavin production and reactions of tobacco leaf tissues (cv. Xanthi-nc) to infiltration with different strains of B. glumae or B. gladioli.

\begin{tabular}{|c|c|c|c|c|}
\hline \multirow{2}{*}{ Strain $^{a}$} & \multicolumn{3}{|c|}{ Period after infiltration (hr) } & \multirow{2}{*}{$\begin{array}{l}\text { Toxoflavin } \\
\text { production }^{b 3}\end{array}$} \\
\hline & 24 & 48 & 72 & \\
\hline \multicolumn{5}{|l|}{ B. glumae } \\
\hline Ku8105 & $\mathrm{H}^{\mathrm{c})}$ & $\mathrm{B}$ & $\mathrm{B}$ & + \\
\hline Ku 8112 & $\mathrm{~B}$ & $B$ & $\mathrm{~B}$ & + \\
\hline Ku 8113 & $\mathrm{~B}$ & $\mathrm{~B}$ & $B$ & + \\
\hline Ku8114 & $\mathrm{B}$ & $\mathrm{B}$ & $\mathrm{B}$ & + \\
\hline 8012 & $\mathrm{~B}$ & $\mathrm{~B}$ & $\mathrm{~B}$ & + \\
\hline 8015 & B & $\mathrm{B}$ & $B$ & + \\
\hline N7401 & $\mathrm{B}$ & $\mathrm{B}$ & $\mathrm{B}$ & + \\
\hline N7505 & $\mathrm{B}$ & $\mathrm{B}$ & $\mathrm{B}$ & + \\
\hline N7501 & $\mathrm{B}$ & $\mathrm{B}$ & $\mathrm{B}$ & + \\
\hline 2 & $\mathrm{~B}$ & $\mathrm{~B}$ & $\mathrm{~B}$ & + \\
\hline III & $\mathrm{B}$ & $\mathrm{B}$ & B & + \\
\hline AZ8224 & $\mathrm{B}$ & $\mathrm{B}$ & $\mathrm{B}$ & + \\
\hline AZ84448 & B & $\mathrm{B}$ & $\mathrm{B}$ & + \\
\hline MAFF301169 & B & B & $B$ & + \\
\hline Ku 8104 & $\mathrm{H}$ & $\mathrm{C}$ & $\mathrm{C}$ & - \\
\hline 8020 & $\mathrm{H}$ & $\mathrm{C}$ & $\mathrm{C}$ & - \\
\hline N7504 & $\mathrm{H}$ & $\mathrm{C}$ & $\mathrm{C}$ & - \\
\hline 805 & $\mathrm{H}$ & $\mathrm{C}$ & $\mathrm{C}$ & - \\
\hline \multicolumn{5}{|l|}{ B. gladioli } \\
\hline MAFF302515 & $\mathrm{B}$ & $\mathrm{B}$ & $\mathrm{B}$ & + \\
\hline MAFF302537 & $\mathrm{B}$ & $\mathrm{B}$ & $\mathrm{B}$ & + \\
\hline MAFF302544 & $\mathrm{B}$ & $\mathrm{B}$ & $\mathrm{B}$ & + \\
\hline MAFF301580 & B & $\mathrm{B}$ & $\mathrm{B}$ & + \\
\hline MAFF302418 & $\mathrm{B}$ & $\mathrm{B}$ & $\mathrm{B}$ & + \\
\hline MAFF302424 & $\mathrm{B}$ & $\mathrm{B}$ & $B$ & + \\
\hline MAFF302409 & B & $\mathrm{B}$ & $\mathrm{B}$ & + \\
\hline MAFF301064 & B & $\mathrm{B}$ & $\mathrm{B}$ & + \\
\hline NLAS1064 & $\mathrm{B}$ & $\mathrm{B}$ & $\mathrm{B}$ & + \\
\hline ATCC10248 & $\mathrm{B}$ & $\mathrm{B}$ & $B$ & + \\
\hline NIAS1065 & $\mathrm{B}$ & $\mathrm{B}$ & $\mathrm{B}$ & - \\
\hline E-14 & $\mathrm{B}$ & $\mathrm{B}$ & $\mathrm{B}$ & - \\
\hline
\end{tabular}

a) Concentration was ca. $10^{\circ} \mathrm{cfu} / \mathrm{ml}$.

b) Toxoflavin production was investigated as follows: each bacterium was inoculated on slant of YPDA and incubated at $30^{\circ} \mathrm{C}$ for 3 days. Toxoflavin secreted in slant was extracted with chloroform. The chloroform extract was evaporated in vacuo and the residue was dissolved in $80 \%$ aqueous methanol. The sample was subjected to visible ultraviolet spectorometory and TLC.

c) $\mathrm{H}$ : healthy (no visible reaction), C: yellowish discoloration, B: brown necrotic lesion. 


\section{Effect of concentrations of infiltrated bacteria on reactions}

To determine the critical concentration of bacteria for necrosis inductivity, bacterial suspensions of both $B$. glumae and B. gladioli were serially diluted and infiltrated into tobacco leaf tissue, respectively. Distinct necrosis was induced at sites infiltrated with concentrated suspensions (higher than $10^{8} \mathrm{cfu} / \mathrm{ml}$ ) within $24 \mathrm{hr}$. However, when bacterial concentration was lower than $10^{7} \mathrm{cfu} / \mathrm{ml}$, infiltrated areas had yellowish discoloration but necrosis did not occur even the 3rd day after infiltration. No visible reaction was observed when bacterial concentration was below $10^{6} \mathrm{cfu} / \mathrm{ml}$ (Table 3 ).

Table 3. Reactions of tobacco leaf tissues (cv. Xanthi-nc) to infiltration of various concentrations of bacterial suspension.

\begin{tabular}{cclcc}
\hline Strain & Serial dilution & \multicolumn{2}{c}{ Period after infiltration (hr) } \\
\cline { 3 - 4 } (Initial concentration) & $10^{6}$ & 24 & 48 & 72 \\
\hline B. glumae & $10^{-1}$ & $\mathrm{~B}^{\mathrm{a}}$ & $\mathrm{B}$ & $\mathrm{B}$ \\
2 & $10^{-3}$ & $\mathrm{~B}$ & $\mathrm{~B}$ & $\mathrm{~B}$ \\
$\left(1.4 \times 10^{9} \mathrm{cfu} / \mathrm{ml}\right)$ & $10^{-3}$ & $\mathrm{C}$ & $\mathrm{C}$ & $\mathrm{C}$ \\
& $10^{-4}$ & $\mathrm{H}$ & $\mathrm{H}$ & $\mathrm{H}$ \\
& $10^{-5}$ & $\mathrm{H}$ & $\mathrm{H}$ & $\mathrm{H}$ \\
& $10^{-6}$ & $\mathrm{H}$ & $\mathrm{H}$ & $\mathrm{H}$ \\
& $10^{\circ}$ & $\mathrm{H}$ & $\mathrm{H}$ & $\mathrm{H}$ \\
\hline B. gladioli & $10^{-1}$ & $\mathrm{~B}$ & $\mathrm{~B}$ & $\mathrm{~B}$ \\
MAFF302544 & $10^{-2}$ & $\mathrm{~B}$ & $\mathrm{~B}$ & $\mathrm{~B}$ \\
$\left(1.4 \times 10^{9} \mathrm{cfu} / \mathrm{ml}\right)$ & $10^{-3}$ & $\mathrm{H}$ & $\mathrm{C}$ & $\mathrm{C}$ \\
& $10^{-4}$ & $\mathrm{H}$ & $\mathrm{H}$ & $\mathrm{H}$ \\
& $10^{-5}$ & $\mathrm{H}$ & $\mathrm{H}$ & $\mathrm{H}$ \\
& $10^{-6}$ & $\mathrm{H}$ & $\mathrm{H}$ & $\mathrm{H}$ \\
& & $\mathrm{H}$ & $\mathrm{H}$ & $\mathrm{H}$ \\
\hline
\end{tabular}

a) See Table 2 .

\section{Response of leaves of various tobacco cultivars to $B$. glumae or B. gladioli}

As shown in Table 4, all toxoflavin productive strains except type strain of B. gladioli induced necrosis in all five tobacco cultivars tested. In the case of toxoflavin non-

Table 4. Reactions of tobacco-leaf tissues of various cultivars to infiltration with toxoflavin producing and non producing strains of B. glumae or B. gladioli.

\begin{tabular}{|c|c|c|c|c|c|c|}
\hline \multirow[b]{3}{*}{$\begin{array}{l}\text { Tobacco } \\
\text { cultivar }\end{array}$} & \multicolumn{6}{|c|}{ Reactions of tobacco leaf tissue } \\
\hline & \multicolumn{3}{|c|}{ B. glumae } & \multicolumn{3}{|c|}{ B. gladioli } \\
\hline & $\begin{array}{c}2 \\
\left.\left(\operatorname{tox}^{+}\right)^{a}\right)\end{array}$ & $\begin{array}{l}\text { Ku8104 } \\
(\text { tox })\end{array}$ & $\begin{array}{c}\text { MAFF } \\
301169^{\prime} \\
\left(\text { tox }^{+}\right)\end{array}$ & $\begin{array}{c}\text { MAFF } \\
302544 \\
\left(\text { tox }^{+}\right)\end{array}$ & $\begin{array}{c}\text { NIAS } \\
1065 \\
(\text { tox })\end{array}$ & $\begin{array}{l}\text { ATCC } \\
10248^{T} \\
\left(\text { tox }^{+}\right)\end{array}$ \\
\hline Xanthi & $\mathrm{B}^{\mathrm{b})}$ & $\mathrm{H}$ & $\mathrm{B}$ & B & $\mathrm{B}$ & $\mathrm{C}$ \\
\hline Xanthi-nc & $\mathrm{B}$ & $\mathrm{H}$ & $\mathrm{B}$ & $\mathrm{B}$ & $\mathrm{B}$ & $\mathrm{B}$ \\
\hline White Burley & $\mathrm{B}$ & $\mathrm{H}$ & $\mathrm{B}$ & $\mathrm{B}$ & $\mathrm{C}$ & $\mathrm{C}$ \\
\hline Bright Yellow & $\mathrm{B}$ & $\mathrm{H}$ & $\mathrm{B}$ & B & $B$ & $\mathrm{C}$ \\
\hline Judy's Pride & $\mathrm{B}$ & $\mathrm{C}$ & $\mathrm{B}$ & $\mathrm{B}$ & $\mathrm{C}$ & $\mathrm{C}$ \\
\hline
\end{tabular}

a) tox': toxoflavin productivity, tox: non-toxoflavin productivity.

b) See Table 2 . 
producing strains, B. glumae Ku8104 induced chorosis in Judy's Pride but not in four other cultivars. Furthermore, B. gladioli NIAS1065 induced chlorosis in two cultivars, White Burley and Judy's Pride but induced necrosis in three other cultivars, Xathi, Xanthi-nc and Bright Yellow. Thus, B. glumae and B. gladioli showed variable levels of necrosis (or chlorosis) depending on the cultivars.

\section{Reaction of rice leaf to bacterial infiltration}

When rice leaves were infiltrated with high concentrations (more than ca. $10^{8} \mathrm{cfu} / \mathrm{ml}$ ) of toxoflavin producing strains, brownish necrosis occurred within $24 \mathrm{hr}$. The browning gradually became distinct, but the size of the lesion remained constant. Subsequently, the central area of necrosis changed from brown to white over time (Fig. 2). No necrosis, however, occurred at infiltration of toxoflavin non-producing strains. Moreover, no significant differences were observed in the response among various species and cultivars of rice (Table 5).

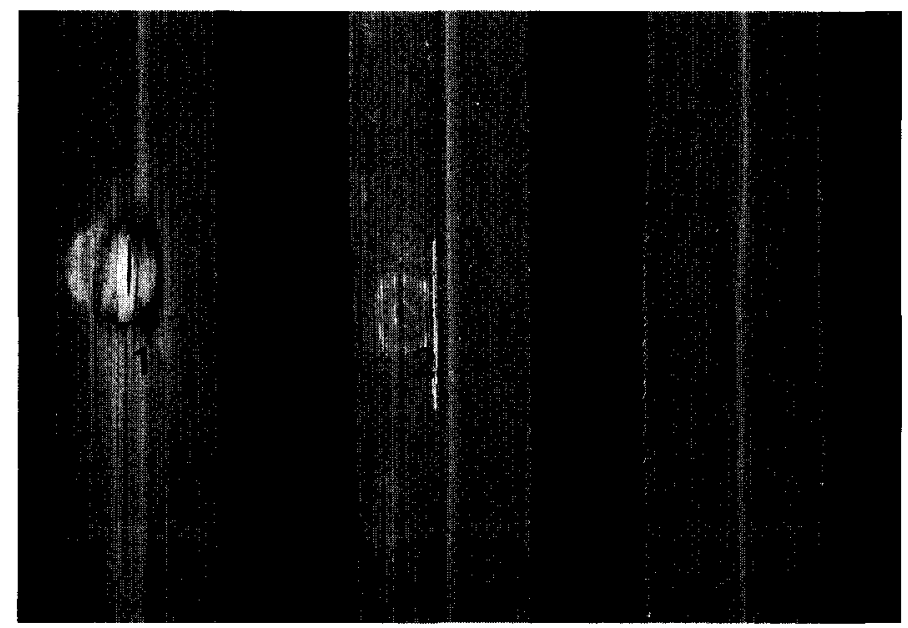

Fig. 2. Reactions of rice leaf tissues infiltrated with toxoflavin producing strain (1) and non-producing strain (2) at $48 \mathrm{hr}$ after infiltration. (3): Control (Watcr).

\section{Reaction of tobacco leaf tissue to infiltration with various inoculum preparations}

To provide information concerning the roles of determinants in B. glumae and $B$. gladioli for induction of necrotic or yellow lesions in tobacco leaves, various inoculum preparations were infiltrated. Of preparations infiltrated, the fractions containing living cells and toxoflavin induced necrosis, but killed cells, EPS and LPS showed no critical effect on necrosis inductivity (Table 6). 
Table 5. Reactions of rice leaf tissues to infiltration with toxoflavin producing and non-producing strains of B. glumae or B. gladioli.

\begin{tabular}{|c|c|c|c|c|}
\hline \multirow{3}{*}{$\begin{array}{l}\text { Cultivar } \\
\text { or } \\
\text { species }\end{array}$} & \multicolumn{4}{|c|}{ Reactions of rice leaf tissue } \\
\hline & \multicolumn{2}{|c|}{ B. glumae } & \multicolumn{2}{|c|}{ B. gladioli } \\
\hline & $\begin{array}{c}2 \\
\left(\operatorname{tox}^{+}\right)^{\text {b] }}\end{array}$ & $\begin{array}{c}\mathrm{Ku} 8104 \\
\left(\mathrm{tox}^{-}\right)\end{array}$ & $\begin{array}{c}\text { MAFF302544 } \\
\left(\text { tox }^{+}\right)\end{array}$ & $\begin{array}{l}\text { NIAS1065 } \\
\left(\text { tox }^{-}\right)\end{array}$ \\
\hline \multicolumn{5}{|l|}{ Oryza sativa } \\
\hline Chugoku No.45 & + & - & + & - \\
\hline Asominori & + & - & + & - \\
\hline Aichiasahi & + & - & + & - \\
\hline Koshihikari & + & - & + & - \\
\hline Nipponbare & + & - & + & - \\
\hline Kinmaze & + & - & + & - \\
\hline Norin No.29 & + & - & + & - \\
\hline Kuju & + & - & + & - \\
\hline Rantai Emas & + & - & + & - \\
\hline O. nivara & + & - & + & - \\
\hline O. barthii & + & - & + & - \\
\hline O. eichingeri & + & - & + & - \\
\hline O. glaberrima & + & - & + & - \\
\hline O. punctata & + & - & + & - \\
\hline
\end{tabular}

a) -: no visible reaction, + : albication or browning.

b) tox : toxoflavin productivity, tox: non-toxoflavin productivity.

Table 6. Reactions of tabacco leaf tissues (cv. Xanthi-nc) infiltrated with various preparations of strains' $\mathrm{S}^{\text {"h }}$ B. glumae and B. gladiloli.

\begin{tabular}{lc}
\multicolumn{1}{c}{ Preparation infiltrated ${ }^{\mathrm{b}}$} & $\begin{array}{c}\text { Reactions of tabacco leaf tissues } \\
(5 \text { days after infiltration })\end{array}$ \\
\hline Living bacteria $\left(\mathrm{ca} .10^{9} \mathrm{cfu} / \mathrm{ml}\right)$ & - \\
Heated bacteria & - \\
UV irradiated bacteria & - \\
Chloroform treated bacteria & - \\
Extracellular polysaccharide solution $(1,000 \mu \mathrm{g} / \mathrm{ml})$ & - \\
Lipopolysaccharide solution $(1,000 \mu \mathrm{g} / \mathrm{ml})$ & + \\
Toxoflavin solution $(1,000 \mu \mathrm{g} / \mathrm{ml})$ &
\end{tabular}

a) B. glumae strain 2 and MAFF301169 ${ }^{\mathrm{T}}$, B. gladiloli strain MAFF302544 and ATCC10248 were used.

b) See the text.

c) +: necrotic lesion, - : no visible reaction.

\section{Reaction of tobacco and rice leaf tissue to infiltration of various concentrations of toxoflavin}

As shown in Table 7 and Fig. 3, when the tobacco and rice leaves were infiltrated with high concentrations (more than $100 \mu \mathrm{g} / \mathrm{ml}$ ) of purified toxoflavin, necrotic lesion was 
induced. This reaction closely resembled symptoms caused by the living cells of toxoflavin producing strains. Thus, the concentration of toxoflavin affects the induction of the necrotic response.

Table 7. Reactions of tobacco and rice leaf tissues to infiltration with different concentrations of toxoflavin

\begin{tabular}{ccc}
\hline $\begin{array}{c}\text { Concentrations } \\
(\mu \mathrm{g} / \mathrm{ml})\end{array}$ & \multicolumn{2}{c}{ Reactions of leaf tissues } \\
\cline { 2 - 3 } 1000 & Tobacco (cv. Xanthi-nc) & Rice (cv. Asominori) \\
100 & $\mathrm{~B}^{\mathrm{H}}$ & $\mathrm{B}$ \\
10 & $\mathrm{~B}$ & $\mathrm{~B}$ \\
1 & $\mathrm{H}$ & $\mathrm{B}$ \\
0.1 & $\mathrm{H}$ & $\mathrm{H}$ \\
Control & $\mathrm{H}$ & $\mathrm{H}$ \\
\end{tabular}

a) See Table 2 .

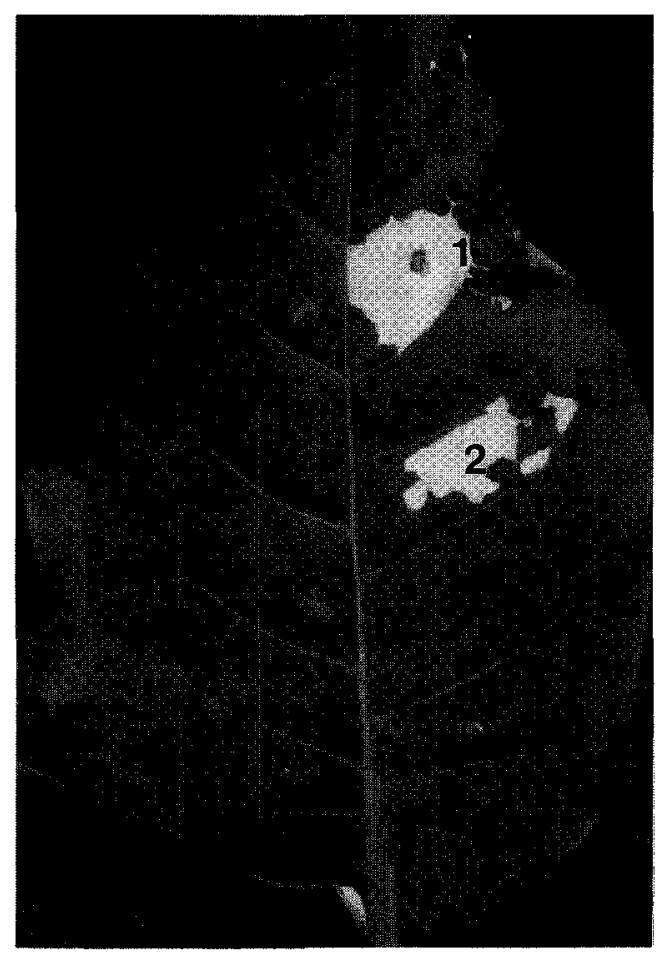

Fig. 3. Reactions of a tobacco leaf injected with different concentrations of toxoflavin. Toxoflavin was prepared as described in the text and infiltrated into tobacco leaf panels. Reactions were photographed $24 \mathrm{hr}$ later. Panel 1: 1,000 $\mathrm{gg} / \mathrm{ml}, 2$ : $100 \mu \mathrm{g} / \mathrm{ml}, 3: 10 \mu \mathrm{g} / \mathrm{ml}, 4: 1 \mu \mathrm{g} / \mathrm{ml}, 5: 0.1 \mu \mathrm{g} / \mathrm{ml}$, 6: Water. 


\section{DISCUSSION}

In our previous paper (Iiyama et al., 1995), it was clearly demonstrated that the producing of toxoflavin by $B$. glumae is closely related to the virulence of the bacterium to rice plants. All toxoflavin producing strains were virulent to rice plants with a few exceptions, whereas all toxoflavin non-producing strains were avirulent.

In the present study, infiltration of virulent strains (toxoflavin producing strains) of B. glumae or B. gladioli to tobacco, an uncongenial test plant, at high concentrations (more than $10^{8} \mathrm{cfu} / \mathrm{ml}$ ), induced necrosis at the infiltrated leaf area within $24 \mathrm{hr}$ of inoculation. This necrosis could be considered the result of HR which has been reported in other combinations of bacteria and incompatible plants.

Rapid necrosis was induced in tobacco leaves infiltrated with all virulent strains of $B$. glumae and not induced by avirulent strains. These results indicate the existence of a close relationship between virulence to rice and necrosis inductivity in uncongenial plants. It appears, therefore, that toxoflavin is essential for pathogenicity in host plants and induction of necrosis in non-hosts.

In the case of $B$. gladioli, two strains (NIAS1065 and E-14), which are toxoflavin non-producing, also induced rapid necrosis in tobacco leaf tissue. Elicitation of HLR in tobacco leaf by $B$. gladioli might not only be the result of toxoflavin but also of other unidentified factors.

\section{REFERENCES}

Evans, L. R. and A. Linker 1973 Production and characterization of the slime polysaccharide of Pseudomonas aeruginosa. J. Bacteriol., 116: $915-924$

Iiyama, K., N. Furuya, K. Hara, N. Nakashima, Y. Takanami and N. Matsuyama 1994 Phytotoxin produced by Pseudomonas glumae Kurita et Tabei, a causal bacterium of the grain and seedling rot of rice. $J$. Fac. Agr., Kyushu Univ., 38: 175-181

Iiyama, K., N. Furuya, Y. Takanami and N. Matsuyama 1995 A role of phytotoxin in virulence of Pseudomonas glumae Kurita et Tabei. Ann. Phytopathol. Soc. Jpn., 61: 470-476

Klement, Z., G. L. Farkas and L. Lovrekovich 1963 Hypersensitive reaction induced by phytopathogenic bacteria in the tobacco leaf. Phytopathology, 54: 474-477

Lucas, L. T. and R. G. Grogan 1969a Serological variation and identification of Pseudomonas lachrymans and other phytopathogenic Pseudomonas nomenspecies. Phytopathology, 59: 1908-1912

Lucas, L. T. and R. G. Grogan $1969 \mathrm{~b}$ Some properties of specific antigens of Pseudomonas lachrymans and other Pseudomonas nomenspecies. Phytopathology, 59: 1913-1917 